\title{
SHOPPING CONVENIENCE UMKM JAKARTA DAN YOGYAKARTA MELALUI VIRAL MARKETING MEDIA FANPAGE
}

\author{
Oleh: \\ Tjipto Djuhartono ${ }^{I}$ \\ Ai Annisaa Utami ${ }^{2}$ \\ Wening Estiningsih ${ }^{3}$ \\ Dosen Program Studi Pendidikan Ekonomi \\ Fakultas Ilmu Pendidikan dan Pengetahuan Sosial \\ Universitas Indraprasta PGRI \\ Email: \\ aiannisaa87@gmail.com
}

\begin{abstract}
ABSTRAK
Penelitian ini bertujuan untuk mengetahui shopping convenience konsumen UMKM yang mengarah pada keuntungan yang di terima oleh konsumen dan kualitas yang diterima oleh konsumen karena pembelian secara on line melalui viral marketing media fanpage. Metode penelitian dilakukan secara deskriptif yang bersifat follow up study dengan objek penelitian UMKM yang terdapat di Yogyakarta dan Jakarta, teknik sampling dilakukan secara purposive. Indikator Shopping convenience yang dibahas dalam penelitian ini adalah ease of use dan usefulness. Hasil dari penelitian ini membuktikan bahwa viral marketing dengan media fanpage meningkatkan shopping convenience konsumen dalam melakukan kegiatan transaksi jual beli online. Tingkat shopping convenience konsumen atas ease of use dimana konsumen percaya bahwa teknologi fanpage dapat digunakan dengan mudah dan bebas dari masalah sebesar $86 \%$ masuk dalam klasifikasi sangat setuju dari total responden, sedangkan shopping convenience konsumen atas usefulness sebesar $79 \%$ masuk dalam klasifikasi setuju dimana konsumen percaya bahwa penggunaan fanpage akan meningkatkan performa mereka dalam membeli dan memilih barang secara online
\end{abstract}

Kata kunci : UMKM, Shopping Convenience, Fanpage, Viral Marketing 


\section{A. PENDAHULUAN}

UMKM sebagai bagian dari pelaku bisnis dituntut untuk memiliki kemampuan strategi pemasaran yang mengikuti perkembangan teknologi dan informasi. Jika strategi pemasaran produk yang dilakukan UMKM masih dilakukan secara manual tanpa mengikuti perkembangan teknologi dan informasi maka dapat dipastikan bahwa daya saing UMKM akan tertinggal jauh dengan para pelaku bisnis lain. Kecepatan dalam menjaring konsumen untuk menciptakan positioning product membutuhkan bantuan teknologi informasi, walaupun dalam bentuk teknologi informasi yang sederhana misalnya melalui media jejaring sosial facebook, twiter, LinkedIn, Youtube, Twitter, Friendster, MySpace, dan Google Hangouts. Berbagai jejaring sosial tersebut menawarkan banyak fitur untuk memberikan kemudahan dalam berkomunikasi dengan konsumen sehingga kecepatan dalam menjaring konsumen lebih efektif dilakukan. Misalnya beberapa fitur yang terdapat di facebook yang dapat dijadikan media untuk sosialisasi dan promosi produk adalah wall, fanpage, upload foto, facebook ads dll.

Survei Deloitte (2015) mengungkapkan bahwa UMKM yang memiliki akses berjualan secara on line telah memanfaatkan media social, dan menguasai kemampuan e-commerce, terbukti mendapatkan keuntungan yang lebih baik dalam hal pendapatan, peluang bisnis. Inovasi, dan daya saing jika dibandingkan dengan UMKM yang masih berjualan secara konvensional. UMKM yang memiliki kemampuan on line dengan tingkatan lanjutan (advance) memperoleh kenaikan pendapatan $80 \%$ lebih cepat dibandingkan dengan UMKM yang masih offline. Selain itu, dibandingkan dengan UMKM yang masih offline, UMKM yang on line tingkat lanjutan memiliki kemungkinan 1,5 kali lebih besar dalam meningkatkan jumlah karyawan yang mereka pekerjakan, selain itu UMKM yang on line memiliki kemampuan 17 kali lebih besar untuk melakukan terobosan dan perubahan inovatif, dan lebih memiliki daya saing secara internasional.

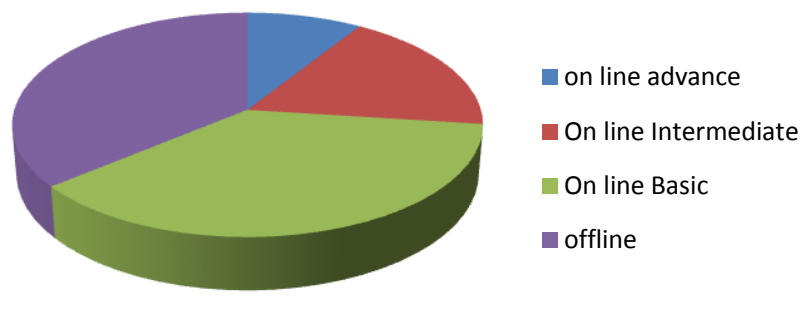

Gambar 1.1

UMKM Di Indonesia Menurut Kemampuan Online

Survei Deloitte (2015) menemukan sekitar sepertiga UMKM ternyata masih offline (36\%) dan sepertiga lainnya hanya memiliki kemampuan online yang masih di tingkat dasar (37\%). Sedangkan yang mempunyai kemampuan 
online dengan tingkatan menengah (intermediet) dan lanjutan (advance) masingmasing baru $18 \%$ dan $9 \%$.

Pemasaran viral adalah cara pemasaran yang berbasis pada internet. Penekanan kata viral adalah untuk menggambarkan bagaimana pesan-pesan yang disampaikan melalui media internet dengan cepat menular bagaikan virus namun dalam konotasi positif, bukan seperti virus yang sifatnya merusak perangkat lunak komputer. Pemasaran viral dianalogikan dengan pemasaran dari mulut ke mulut atau word-ofmouth yang penyebaran pesannya dilakukan dari satu pihak kepada pihak lain. Dalam pemasaran viral diharapkan terjadi efek multi ganda karena dari satu orang yang menerima pesan dapat menyampaikan kepada puluhan bahkan ratusan pengguna internet lainnya.

Penelitian ini bertujuan untuk mengukur tingkat shopping convinence konsumen ketika melakukan transaksi jual beli secara on line. Objek penelitian ini adalah UMKM yang terdapat di Kota Jakarta dan Yogyakarta pengguna media fanpage dalam proses pemasaran on line . Fedback dari penelitian ini diharapkan menjadi umpan balik bagi para pelaku bisnis UMKM Yogyakarta dan Jakarta untuk meningkatkan kualitas desain fanpage yang telah digunakan. Kenyamanan dalam berbelanja merupakan factor utama yang harus di maintance oleh para pelaku bisnis, baik pelaku bisnis off line maupun pelaku bisnis on line. Hal ini disebabkan karena follow up dari shopping convinence adalah perilaku pembelian berulang atau usage intention. Dari penelitian pengguna-an internet Gefen et al. (2003) mendefinisikan usage intention adalah niat penggunaan kembali terutama ditujukan pada individu untuk melakukan pembelian secara online melalui internet. Niat untuk selalu menggunakan online dalam pembelian dan merekomendasikan pembelian online (Hong, 2006). mengembangkan indikator pembelian berulang sebagai berikut: niat penggunaan kembali, dan rekomendasi

\section{B. KAJIAN PUSTAKA}

\section{Kriteria UMKM}

Kriteria Usaha Kecil Dan Menengah berdasar Perkembangan selain berdasar Undang-undang tersebut, dari sudut pandang perkembangannya Rahmana (2008) mengelompokkan UMKM dalam beberapa kriteria, yaitu:

1. Livelihood Activities, merupakan Usaha Kecil Menengah yang digunakan sebagai kesempatan kerja untuk mencari nafkah, yang lebih umum dikenal sebagai sektor informal. Contohnya adalah pedagang kaki lima.

2. Micro Enterprise,merupakan Usaha Kecil Menengah yang memiliki sifat pengrajin tetapi belum memiliki sifat kewirausahaan.

3. Small Dynamic Enterprise,merupakan Usaha Kecil Menengah yang telah memiliki jiwa kewirausahaan dan mampu menerima pekerjaan subkontrak dan ekspor

4. Fast Moving Enterprise,merupakam Usaha Kecil Menengah yang telah memiliki jiwa kewirausahaan dan akan melakukantransformasi menjadi Usaha Besar (UB). 


\section{Viral Marketing}

Inti dari viral marketing adalah strategi pemasaran yang dapat menyebabkan orang-orang membicarakan bisnis yang dilakukan perusahaan di kalangan sosialisasi teman-teman mereka atau jejaring sosial mereka. Dalam dunia pemasaran konvensional, hal ini dikenal dengan istilah public relations atau network marketing yang memanfaatkan asosiasi, komunitas atau jaringan temanteman untuk menyebarkan pesan pemasaran tentang bisnis perusahaan.

Kelebihan yang bisa dilakukan oleh viral marketing adalah kemampuannya untuk menduplikasikan kegiatan komunikasi pemasaran ke seluruh penjuru internet. Karena jaringan internet tak terbataskan oleh batas waktu dan zona geografis maka memungkinkan komunikasi pemasaran tersebar dan meluas kepada seluruh pengguna internet yang ada di seluruh belahan dunia.

Istilah viral digunakan utuk menggambarkan penyebaran pesan yang sangat cepat dan luas. Swanepoel et.al (2009:3) mengutip pendapat Porter dan Golan (2006) yang menyatakan bahwa penyebaran viral dapat dibandingkan dengan analogi sekali bersin dimana setiap kali bersin akan melepaskan kurang lebih 2 juta partikel. Datta et.al (2005:72) menyatakan bahwa dalam model viral, seseorang menginfeksi beberapa orang dengan sebuah tawaran dan kemudian orang tersebut akan menyebarkannya kepada pihak lain atau teman, sampai semua lingkungan virtual dapat terekspos.

Terminologi pemasaran viral juga sering dikaitkan bahkan dipersamakan dengan istilah lain. Cruz dan Fill (2008:745) mengutip beberapa istilah yang dikemukakan oleh beberapa orang antara lain menurut Blattberg dan Deighton (1991) yaitu interactive marketing, Goldenberg et.al (2001) menamakan sebagai internet word of mouth dan word of mouse, Shukla, Timira. (2010)) menamakan stealth marketing, Scott, David Meerman. (2007) menamakan sebagai referral marketing. dan Thomas (2004) mencoba menggabungkan semua ide-ide tersebut dengan terminologi buzz marketing.

Dalam Swanepoel et.al (2009:3), Thomas (2004) mendefinisikan buzz marketing sebagai penguatan usaha-usaha pemasaran oleh pihak ketiga melalui pengaruh mereka yang dapat bersifat pasif ataupun aktif. Sedangkan istilah word of mouse karena kekuatan dibalik konsep pemasaran viral terletak pada pengaruh kekuatan komunikasi dari mulut ke mulut diantara individu-individu yang menggunakan media elektronik.

\section{Shopping Convenience Konsumen Online}

Shopping Convenience mengarah pada keuntungan yang di terima oleh konsumen dan kualitas yang diterima oleh konsumen karena pembelian secara on line. Davis et al. (1989) memberikan beberapa indicator Shopping Convenience yaitu ease of use (Kemudahan Penggunaan): ease of learn (Kemudahan Belajar), controllable (Terkendali), clear and understandable (Jelas dan Dimengerti), flexible (fleksibel), ease to become skillful (Kemudahan Untuk Menjadi Terampil). Ease of use menunjukkan bahwa kemudahan penggunaan, yaitu tingkatan dimana user percaya bahwa teknologi/sistem tersebut dapat digunakan 
dengan mudah dan bebas dari masalah. Intensitas penggunaan dan interaksi antara pengguna dengan sistem juga dapat menunjukkan kemudahan penggunaan.

Selain ease of use Davis et al. (1989) juga mengemukakan bahwa indicator Shopping Convenience yang lain adalah usefulness. Usefulness sebagai keyakinan akan kemanfaatan, yaitu tingkatan dimana user percaya bahwa penggunaan teknologi/sistem akan meningkatkan performa mereka dalam bekerja. Thompson et al. (1991) juga menyebutkan bahwa individu akan menggunakan teknologi informasi jika mengetahui manfaat positif atas penggunaannya. Davis et al. (1989) memberikan beberapa indikator perceived usefulness (Persepsi Kegunaan), yaitu work more quickly (Bekerja Lebih Cepat), job performance (Kinerja), increase productivity (Meningkatkan Produktifitas), makes job easier (Membuat Pekerjaan Lebih Mudah), useful (Berguna).

\section{METODE PENELITIAN}

Penelitian ini menggunakan pendekatan kualitatif. Pendekatan kualitatif adalah suatu proses penelitian dan pemahaman yang berdasarkan pada metodologi yang menyelidiki suatu fenomena sosial dan masalah manusia. Didalam pelaksanaan penelitian ini, metode yang digunakan peneliti adalah metode deskritif yang bersifat follow up study. Dengan metode deskriptif, penelitian memungkinkan untuk melakukan hubungan antar variabel, menguji hipotesis, mengembangkan generalisasi, dan mengembangkan teori yang memiliki validitas universal. Metode deskriptif adalah suatu metode dalam meneliti status sekelompok manusia, objek, kondisi, sistem pemikiran ataupun suatu kelas peristiwa pada masa sekarang. Tujuan dari penelitian deskritif ini adalah untuk membuat deskripsi, gambaran atau lukisan secara sistematis, faktual dan akurat mengenai fakta, sifat serta hubungan antar fenomena yang diselidiki ( Sugiyono, 2007 : 11 ). Beberapa fenomena yang dilihat hubungannya adalah penggunaan viral marketing dengan menggunakan fanpage sebagai bagian dari strategi marketing untuk menciptakan shopping convenience untuk konsumen. berikut:

Beberapa metode pengumpulan data dalam penelitian ini adalah sebagai

1. Wawancara dalam bentuk in-depth interview

2. Observasi dalam bentuk participant observation

3. Focus Group Discussion (FGD

\section{HASIL DAN PEMBAHASAN}

\section{Karakteristik Responden}

Adapun karakteristik responden dari segi jenis kelamin dan usia, adalah sebagai berikut: 
a) Karakteristik responden berdasarkan jenis kelamin

Table 1

Karakteristik Berdasarkan Jenis Kelamin

\begin{tabular}{llll}
\hline No & Jenis kelamin & Jumlah & Persentase (\%) \\
\hline 1 & Wanita & 67 & 67 \\
\hline 2 & Pria & 33 & 33 \\
\hline \multicolumn{2}{l}{ Jumlah } & 100 & 100 \\
\hline \multicolumn{2}{l}{ Sumber: Data diolah dari hasil kuesioner }
\end{tabular}

Berdasarkan tabel diatas menunjukkan bahwa responden berjenis kelamin pria sebanyak 33 orang atau sebesar 33\% sedangkan yang berjenis kelamin wanita sebanyak 67 orang atau sebesar $67 \%$.. Lebih dari $50 \%$ konsumen on line untuk UMKM di dominasi oleh wanita

b) Karakteristik responden berdasarkan usia

Tabel 2

Karakteristik Berdasarkan Usia

\begin{tabular}{llll}
\hline No & Usia (tahun) & Jumlah & Persentase (\%) \\
\hline 1 & $25-30$ & 14 & $14 \%$ \\
\hline 2 & $31-40$ & 28 & $28 \%$ \\
\hline 3 & $>41$ & 58 & $58 \%$ \\
\hline Jumlah & 100 & $100 \%$ \\
\hline \multicolumn{3}{c}{ Sumber: Data diolah dari hasil kuesioner }
\end{tabular}

Berdasarkan tabel diatas menunjukkan bahwa usia 31-40 tahun merupakan responden terbanyak yaitu 28 orang (28\%), usia $>41$ tahun sebanyak 58 orang (58\%), usia 25-30 tahun sebannyak 14 orang (14\%). Sebagian besar responden yang terlibat dalam penelitian ini mayoritas adalah berusai di atas 41 orang

\section{Tanggapan Responden}

a) Tingkat shopping convenience konsumen atas ease of use

Tabel 3

Fanpage mudah di gunakan

\begin{tabular}{lllll}
\hline Kategori Penilaian & Kode & Bobot & Frekuensi (n) & $\begin{array}{l}\text { Persentase } \\
(\boldsymbol{\%})\end{array}$ \\
\hline Sangat Setuju & SS & 5 & 80 & $80 \%$ \\
\hline Setuju & S & 4 & 6 & $6 \%$ \\
\hline Cukup Setuju & CS & 3 & 2 & $2 \%$ \\
\hline
\end{tabular}




\begin{tabular}{lllll}
\hline Tidak Setuju & TS & 2 & 8 & $8 \%$ \\
\hline Sangat Tidak Setuju & STS & 1 & 4 & $4 \%$ \\
\hline Jumlah & & & 100 & $100 \%$ \\
\hline
\end{tabular}

Sumber: Diolah Penulis

Berdasarkan keterangan pada tabel 3 diatas dapat dijelaskan, bahwa responden berpendapat sangat setuju dan setuju sebanyak 86 orang $(86 \%)$ artinya konsumen percaya bahwa teknologi fanpage dapat digunakan dengan mudah dan bebas dari masalah. Catatan penting dari hasil data diatas menunjukkan bahwa konsumen merasa nyaman melakukan jual beli on line dengan fanpage karena fanpage mudah digunakan jika dibandingkan dengan media online laiinya. Salah satu indicator kemudahan bertransaksi dengan fanpage adalah aplikasi fanpage dalam facebook telah dimiliki otomatis oleh konsumen, mereka hanya melakukan aktivitas like pada page yang menawarkan barang dan produk untuk UMKM Yogyakarta dan Jakarta.

b) Tingkat shopping convenience konsumen atas usefullness

Tabel 4

Fanpage bernilai guna

\begin{tabular}{lllll}
\hline Kategori Penilaian & Kode & Bobot & Frekuensi (n) & $\begin{array}{l}\text { Persentase } \\
(\%)\end{array}$ \\
\hline Sangat Setuju & SS & 5 & 73 & $73 \%$ \\
\hline Setuju & S & 4 & 6 & $6 \%$ \\
\hline Cukup Setuju & CS & 3 & 10 & $10 \%$ \\
\hline Tidak Setuju & TS & 2 & 7 & $7 \%$ \\
\hline Sangat Tidak Setuju & STS & 1 & 4 & $4 \%$ \\
\hline Jumlah & \multicolumn{5}{l}{100} & $100 \%$ \\
\hline \multicolumn{5}{r}{ Sumber: Diolah Penulis }
\end{tabular}

Berdasarkan keterangan pada tabel 4 diatas dapat dijelaskan, bahwa responden berpendapat sangat setuju dan setuju sebanyak 79 orang $(79 \%)$ artinya konsumen percaya bahwa penggunaan fanpage akan meningkatkan performa mereka dalam membeli dan memilih barang secara online. Proses pemilihan barang yang akan dibeli memerlukan beberapa pertimbangan dari konsumen. Penggunaan fanpage membantu konsumen dalam memutuskan produk yang akan di beli. Penggunaan sosial media dalam pemasaran, bertujuan untuk mewujudkan adanya interaksi dan komunikasi antara pemasar dan konsumen. Interaksi dan komunikasi tersebut salah satunya untuk mengetahui jenis kebutuhan konsumen, serta tingkat kepuasan konsumen terhadap produk yang ditawarkan. Pembelian ulang merupakan hasil dominasi pasar oleh suatu perusahaan yang berhasil membuat produknya menjadi satu-satunya alternatif yang tersedia.

\section{E. SIMPULAN}

Tingkat shopping convenience konsumen atas ease of use dimana konsumen percaya bahwa teknologi fanpage dapat digunakan dengan mudah dan bebas dari masalah sebesar 86\% masuk dalam klasifikasi sangat setuju dari total responden, sedangkan shopping convenience konsumen atas usefulness sebesar 79,5\% masuk dalam klasifikasi setuju dimana konsumen percaya bahwa penggunaan fanpage 
akan meningkatkan performa mereka dalam membeli dan memilih barang secara online

\section{DAFTAR PUSTAKA}

Cruz, Danilo. (2008). Evaluating viral marketing: isolating the key criteria. Marketing Intelligence \& Planning, Volume 26 No.7

Datta, Palto R.et.al. (2005). Viral Marketing: New Form of Word-of-Mouth through Internet. The Business Review, Cambridge, Voume 3, No. 2

Davis, F.D. (1989). Perceived Usefullness. Perceived Ease of Use of Information Technology. Management Information System Quarterly. 13(3): 319-340.

Deloitte. (2015). UMKM Pemicu Kemajuan Indonesia: Instrumen Pertumbuhan Nusantara. Jakarta

Gefen, D., Karahanna, E. \& Straub, D.W. (2003). Trust and TAM in Online Shopping: An Integrated Model. Management Information System Quarterly. 27(1): 51-90.

Hong, J., Thong, J. \& Yan, K.T. (2006). Understanding Continued Information Technology Usage Behavior: A Comparison of Three Models in the Context of Mobile Internet, Decision Support Systems. 42(3): 1819-1834.

Porter dan Golan (2006). Word of Mouth and Viral Marketing: Taking the Temperature of the Hottest Trends in Marketing. Journal of Consumer Marketing, Vol. 25 No. 3

Rahmana. (2008). Manajemen Pemasaran UMKM. Jakarta: Salemba Empat.

Swanepoel, Celeste et.al. (2009). Virally inspired: A review of the theory of viral stealth marketing. Australasian Marketing Journal, Volume 17, Iss.

Thompson, R. \& Howell, H. (1991). Personal Com-puting: Toward a Conceptual Model of Utili-zation. Management Information System Quarterly. 15(1): 125:143.

Scott, David Meerman. (2007). The New Rules of Marketing and PR. John Wiley \& Sons, Inc., Hoboken, New Jersey

Shukla, Timira. (2010). Factors Affecting Internet Marketing Campaigns with Reference to Viral and Permission Marketing. The IUP Journal of Management Research, Vol. IX No. 1 